Journal of Engineering and Applied Sciences 14 (10): 3434-3443, 2019

ISSN: 1816-949X

(C) Medwell Journals, 2019

\title{
The Priority of Settlement Sanitation Services Based on Sanitation Risk Level in Mojokerto
}

\author{
${ }^{1}$ Mohammad Debby Rizani, ${ }^{2}$ Antariksa, ${ }^{3}$ Surjono and ${ }^{3}$ Ismu Rini Dwi Ari \\ ${ }^{1}$ Department of Civil Engineering, \\ ${ }^{2}$ Department of Architecture, \\ ${ }^{3}$ Department of Urban and Regional Planning, Faculty of Engineering, \\ Universitas Brawijaya, Malang, Indonesia
}

\begin{abstract}
Sanitation management in Mojokerto city has been designed in technocratic ways in the forms of programs and activities which have to be supported by adequate community participation in order to optimize proper sanitation services. Priority sanitation service has been the key to the success of sanitation service improvement. This research was conducted to determine the areas/villages to receive priority sanitation services based on the sanitation risk level which was analyzed using both descriptive qualitative and quantitative methods. Research data including primary and secondary data were collected through questionnaires, interviews and observations. The priority sanitation services for high-risk areas were determined using Hanlon method, a method that measured the priority based on priority scales and problem solving. The priority was determined by weighing the impact and exposure in the forms of percentages that describe the influence of a research variable to the outcome. The prioritized villages are directly proportional with the results of the sanitation risk analysis in the management of domestic wastewater and household waste. Seen from the city planning perspective using spatial interaction approach, adjacent areas greatly affect each others. In addition, spatial comparison approach also regarded the comparison of spatial areas in determining the priority scale of services for domestic wastewater and household waste management. Highly-prioritized areas needed special treatment in the forms of programs and short-term plans while the programs designed for the less-prioritized areas and non-prioritized areas could be realized in medium or long-term.
\end{abstract}

Key words: Sanitation management, prioritized sanitation services, areas with high saintation risk, spatial approach, long-term, less-prioritized, household

\section{INTRODUCTION}

Environmental sanitation refers to health status of an environment that includes housing, sewage disposal, supply of clean water, etc. (Notoatmodjo, 2012). According to Umar (2008) and Craven et al. (2013), environmental sanitation deals with the management of environmental factors that influence human health. In presidential regulation number 185 of 2014. Sanitation is defined as any effort made to ensure the fulfillment of conditions required for heathy life through sanitation development. Sanitation development as stated by Rizki and Saleh (2007) can be divided into 3 fields, namely the development of waste water management, solid waste management and drainage channels. Sanitation development is an effort to improve the quality and provision of domestic wastewater services, household waste and environmental drainage management in an integrated and sustainable manner through improved planning, institutional factors, program implementation and adequate supervision. Social, cultural, economic and environmental aspects are quite dynamic and ever changing that might influence the development (Adams, 2008).

Problems related to sanitation management in Mojokerto city have been identified from the results of surveys and interviews with some informants and reviews on sanitation planning documents. The data included the ones related to sanitation services condition by Mojokerto (2017) which has reached 78\%, data of latrines ownership with safe septic tanks $25.4 \%$, unavailability of IPLT (sewage treatment plant), inability to reach ODF (Open Defecation Free) in 2.388 families who have defecated, some residents still threw their waste into water/rivers, the overloaded landfill (final processing site), lack of transportation facilities, the existence of 103 ha

Corresponding Author: Mohammad Debby Rizani, Department of Civil Engineering, Faculty of Engineering, Universitas Brawijaya, Malang, Indonesia 
puddle with a pool of 1-2 $\mathrm{h}$, lack of public awareness for clean and healthy lifestyle (PHBS), sanitation management that had not yet been integrated (sectoral), limited resources and funding from the government for sanitation management, unavailability of regional regulations concerning waste water and waste management (Anonymous, 2004, 2008, 2009, 2014a, b, 2017).

Political and sectoral interests, inadequate human resources and sanitation facilities, the cost of sanitation development, limited land and the low level of community and private participation appeared as problems faced by Mojokerto city's government in increasing access to settlement sanitation services. It takes synergic works, cross-sectoral cooperation and community participation to support sanitation development for better sanitation services as targeted. Therefore, the sanitation management which had been technocratically planned in the forms of various programs and activities have to be supported by stronger community participation to help optimizing proper sanitation services. Prioritization of sanitation services was regarded as one of the keys to the success of the improvement of access to sanitation services. The determination of sanitation service priority was made based on the level of sanitation health risk in each village. Sanitation health risks were triggered by low quality of life, health, buildings and/or the environment due to inadequate access to sanitation services and weak behavior related to clean and healthy living.

This research focused on the priority of settlement sanitation services based on the level of sanitation health risk Mojokerto city. In this research, the term sanitation management is only limited to domestic waste water and household waste.

Literature review: Within the context of community development, participation refers to active process in which beneficiaries have certain influence in determining the direction and implementation of development projects instead of merely receiving the benefits of the projects. This definition implies two main aspects, active processes and how beneficiaries influence the direction and implementation of development projects. Community participation in a development project might influence the direction and implementation of the project in which participation would be in the forms of time, energy and fund contributions (Mardikanto, 1988).

Community participation is a dynamic and multi-dimensional domain that might appear in various forms which might change during or after the implementation of a project to meet the current interests and needs. One indicator that can be used to assess community participation is the condition of infrastructure. It is said that the greater the participation, the better the condition of the infrastructure. Infrastructure conditions can be measured by the functionality of the infrastructure. However, weak infrastructure is not only triggered by lack of community participation as it might be caused by wrong planning and implementation (Mardikanto, 1988).

There are always causes and impacts of a risk that occurs. Every activity has its own risks. Hence, early identification of risks can guarantee better planning. Furthermore, a system has to be established to minimize the risks to the lowest limit (Asiyanto, 2009).

According to Wideman in Husein, risk is the accumulated effect of opportunities that occur in uncertain events which might affect the achievement of predetermined goals and objectives. Risk is also associated with the possibility of the occurrence of unwanted adverse consequences or uncertainty that will affect the cost, schedule and quality of the project. Other definitions of risks have also been proposed by Darmawi (2010) including:

Risk is the chance of loss: This kind of risk is usually measured to show a condition that allows loss to occur.

Risk is the possibility of loss: This kind of risk shows that the possible risk might cause to losses if it is not immediately mitigated.

Risk is uncertainty: In this context, risk is viewed as something that deals with and caused by uncertainties. Generally, risks refer to any potential of loss that might disrupt the achievement of certain predetermined targets due to uncertainties.

Sanitation health risks are caused by decreases in quality of life, health, building and/or environment due to inadequate access to sanitation services and clean and healthy living behavior. High-risk areas are areas that are prone to risks in sanitation management. High-risk areas are mapped based on the data related to the risk impact and exposure. The impact data include, population, population density, poverty rate, urban and rural function. Whilst, exposure data include: sanitation risk index, secondary data and local government perceptions. The sanitation risk index is the outcome of environmental health risk assessment done based on the results of a participatory survey in certain city that is used to evaluate the sanitation facilities and community behavior related to family hygiene and sanitation. The sanitation risk index 
provides a quantitative description of the risks of sanitation that exist in a community. Local government's perceived data is obtained from the assessment of settlement sanitation management using questionnaires and interviews (Anonymous, 2014a, b).

The impact and exposure data compilations which were collected through sanitation instrument (Excel), areas with high sanitation risk were classified as follows:

- $\quad$ Strata 1-low-risk areas (Green)

- Strata 2-medium-risk areas (Blue)

- Strata 3-high-risk areas (Yellow)

- $\quad$ Strata 4-extremely high-risk areas (Red)

This classification can be used to determine the areas/villages in Mojokerto city that should be prioritized to receive improvement in sanitation services. Higher risk of sanitation health shows the priority of sanitation services.

\section{MATERIALS AND METHODS}

This research was conducted using both qualitative and quantitative approaches as this research aimed to obtain deeper understanding of the planning and process of sanitation management in community settlements. The objects of this research included the current conditions of sanitation management and the level of sanitation services in Mojokerto city.

To determine the priority of sanitation services in Mojokerto city, the level of environmental sanitation risk was analyzed using Hanlon method that assessed the prioritization based on problem solving. The results of analysis on sanitation risk classified the level of sanitation risk in each area/village. This classification showed areas or villages that are prone to the risk related to sanitation management. This classification also regarded the impact data and exposure data. Impact data included the population, population density, poverty rate, urban/rural function while exposure data were sanitation risk index, secondary data and local government perceptions.

Those data were then weighed and presented in percentages that describe the level of influence of certain variable on the results described as follows:

$$
\begin{gathered}
\text { Impact score }=(\text { Population } \times \text { weigh\% })+ \\
(\text { Population density } \times \text { weigh\% })+ \\
(\text { Poverty rate } \times \text { weigh\% })+ \\
(\text { Urban/rural index weigh\%) }
\end{gathered}
$$

Highest impact score-lowest impact score, then divided by 4 ranges. The higher the impact score, the higher the sanitation risk:

$$
\begin{aligned}
& \text { Exposure score }=(\text { Score of secondary data } \times \\
& \text { weigh } \%)+(\text { Score of OPD perception } \times \\
& \text { weigh } \%)+(\text { IRS score } \times \text { weigh } \%)
\end{aligned}
$$

Highest exposure score-lowest exposure score, then divided by 4 ranges. The higher the exposure score, the higher the sanitation risk.

The compiled data (impact $\times$ exposure) showed the classification of areas prone to sanitation risks obtained from the instrument (microsoft excel) based on interval data (average gap of maximum to minimum scores of each indicator) categorized into 4 :

- Risk 1 low-risk area (Green)

- $\quad$ Risk 2 medium-risk area (Blue)

- Risk 3 high-risk area (Yellow)

- Risk 4 extremely high-risk area (Red)

The number of respondents to determine local government's perception in the evaluation of sanitation management performance, the following formula proposed by Slovin in Sevilla Consuelo was employed:

$$
\mathrm{n}=\mathrm{N} /\left(1+\mathrm{N}(\lambda)^{2}\right)
$$

Where:

$$
\begin{aligned}
& \mathrm{n}=\text { Total sample } \\
& \mathrm{N}=\text { Total population }(141.824 \text { people }) \\
& \lambda=\text { Margin or error }(10 \%) \text { regarding to the lim } \\
& \text { number of parties who understood the planning } \\
& \quad \mathrm{n}=141.824 /\left(1+141.824(0.1)^{2}\right)= \\
& \quad 99.62 \approx 100 \text { people }
\end{aligned}
$$$$
\lambda=\text { Margin or error }(10 \%) \text { regarding to the limited }
$$

Based on this measurement, there were at least 100 samples needed. The respondents were selected from several regional government parties (Bappeda, $\mathrm{KLH}, \mathrm{PU}$, Dinkes, DKP) in charge of sanitation management as follows:

- Bappeda: 10 people

- Kantor lingkung an hidup: 20 people

- Dinas Pekerjaan umum: 10 people

- Dinas Kesehatan: 40 people

- Dinas Kebersihan dan pertamanan: 20 people

The sampling was prioritized to those who were directly involved in sanitation management in the region. This 
research aimed to obtain and explore more comprehensive information about settlement sanitation management in Mojokerto city from local government representatives.

\section{RESULTS AND DISCUSSION}

Mojokerto is the only city in East Java that has the smallest area of 1.646 ha. The administrative area of the city is divided into three regencies, Prajuritkulon Regency, Magersari Regenci and Kranggan. There are 18 villages, 655 neighborhood associations, 176 community associations and 72 dusun or sub-villages (Anonymous, 2017).

Overall, the areas of Mojokerto city are located along the river stream areas of Brantas River or Daerah Aliran Sungai (DAS) which location is included in national strategic river area. The area of Brantas River is divided into 4 DAS including DAS Brantas, DAS Tengah, DAS Ringin Bandulan and DAS Kondangmerak. The river consisted of 9 Sub DAS including DAS Brantas Hulu, sub DAS Brantas Tengah, Sub DAS Ngorowo/Ngasinan, sub
DAS Konto, sub DAS Widas, Sub DAS Brantas Hilir, sub DAS Tengah, sub DAS Ringin Bandulan dan sub DAS Kondang Merak. DAS in Mojokerto city. Based on its sub DAS, Mojokerto city belongs to the areas of sub DAS Brantas Hilir, covering some part of Gunung Gedangan village, Meri village, Miji village, Balongsari village, Jagalan village, Sentanan village, Purwotengah village, some part of Mentikan village, Kauman village, Gedongan village, Magersari village, Wates village and Kedudung village (Table 1-4).

To improve the sanitation service, prioritization of sanitation services is regarded a proper way. The prioritization allows government and non-government organizations that concern about sanitation issues to be able to design and plan effective programs and activities to be implemented for short, medium and long terms. In order to determine areas to receive settlement sanitation services, researchers conducted an analysis based on the risk of sanitation in each village. The classification of risky areas would be used to determine the areas or villages in Mojokerto city that would be prioritized for

Table 1: Name and total area of each regency and the number of villages

\begin{tabular}{|c|c|c|c|c|c|}
\hline \multirow[b]{3}{*}{ Regency } & \multirow[b]{3}{*}{ Number of villages } & \multicolumn{4}{|c|}{ Total area } \\
\hline & & \multicolumn{2}{|c|}{ Administrative area } & \multicolumn{2}{|c|}{ Developed area } \\
\hline & & $(\mathrm{Ha})$ & The total area $(\%)$ & $(\mathrm{Ha})$ & The administrative area $(\%)$ \\
\hline Prajurit Kulon & 6 & 641.5 & 39.06 & 266.9 & 41.61 \\
\hline Magersari & 6 & 658.5 & 40.10 & 382.9 & 58.15 \\
\hline Kranggan & 6 & 342.3 & 20.84 & 213.0 & 62.23 \\
\hline Total & 18 & 1.642 .3 & 100 & 863 & \\
\hline
\end{tabular}

BPS of Mojokerto city 2017

Table 2: Impact data of Mojokerto city

\begin{tabular}{|c|c|c|c|c|}
\hline Regency/Villages & Total population & Population density & Number of poor families & Area classification \\
\hline \multicolumn{5}{|l|}{ Prajurit Kulon } \\
\hline Mentikan & 2.005 & 500 & 534 & 1 \\
\hline Pulorejo & 2.009 & 202 & 524 & 1 \\
\hline Kauman & 849 & 207 & 231 & 1 \\
\hline Blooto & 1.653 & 114 & 402 & 1 \\
\hline Surodinawan & 2.362 & 105 & 463 & 1 \\
\hline Prajurit Kulon & 2.218 & 189 & 605 & 1 \\
\hline \multicolumn{5}{|l|}{ Magersari } \\
\hline Magersari & 1.593 & 210 & 297 & 1 \\
\hline Gedongan & 629 & 206 & 98 & 1 \\
\hline Balongsari & 2.193 & 313 & 504 & 1 \\
\hline Wates & 5.483 & 190 & 591 & 1 \\
\hline Kedundung & 4.349 & 150 & 1.207 & 1 \\
\hline Gunung Gedangan & 1.925 & 95 & 534 & 1 \\
\hline \multicolumn{5}{|l|}{ Kranggan } \\
\hline Meri & 2.319 & 158 & 420 & 1 \\
\hline Miji & 2.498 & 273 & 596 & 1 \\
\hline Kranggan & 3.655 & 183 & 905 & 1 \\
\hline Sentanan & 639 & 203 & 117 & 1 \\
\hline Purwotengah & 516 & 156 & 66 & 1 \\
\hline Jagalan & 877 & 286 & 157 & 1 \\
\hline
\end{tabular}

Analyzed research data 2018 
Table 3: Exposure data of domestic wastewater in Mojokerto city

\begin{tabular}{|c|c|c|c|c|c|c|c|c|c|c|}
\hline \multirow[b]{3}{*}{ Regency/Villages } & \multirow{3}{*}{$\begin{array}{l}\text { IRS of domestic } \\
\text { wastewater }\end{array}$} & \multicolumn{4}{|c|}{ Secondary data } & \multirow{2}{*}{\multicolumn{5}{|c|}{ OPD perception }} \\
\hline & & & & & & & & & & \\
\hline & & $(\mathrm{KK})$ & access & SPALD-S (KK) & SPALD-T (KK) & Bappeda & $\mathrm{KLH}$ & $\mathrm{PU}$ & Dinkes & DKP \\
\hline \multicolumn{11}{|l|}{ Prajurit Kulon } \\
\hline Mentikan & 39 & 190 & 0 & 1.815 & 0 & 4 & 3 & 3 & 3 & 4 \\
\hline Pulorejo & 46 & 107 & 4 & 1.564 & 333 & 1 & 4 & 3 & 3 & 1 \\
\hline Kauman & 71 & 203 & 0 & 526 & 120 & 2 & 3 & 3 & 2 & 2 \\
\hline Blooto & 73 & 82 & 41 & 1.323 & 207 & 1 & 2 & 3 & 2 & 1 \\
\hline Surodinawan & 25 & 37 & 0 & 1.924 & 400 & 1 & 2 & 2 & 3 & 1 \\
\hline Prajurit Kulon & 36 & 57 & 123 & 1.968 & 70 & 2 & 2 & 2 & 2 & 1 \\
\hline \multicolumn{11}{|l|}{ Magersari } \\
\hline Magersari & 57 & 48 & 0 & 1.545 & 0 & 3 & 2 & 2 & 2 & 2 \\
\hline Gedongan & 65 & 54 & 0 & 535 & 40 & 2 & 3 & 2 & 2 & 3 \\
\hline Balongsari & 52 & 105 & 0 & 1.823 & 265 & 2 & 3 & 2 & 2 & 2 \\
\hline Wates & 62 & 0 & 0 & 5.383 & 100 & 1 & 3 & 1 & 2 & 2 \\
\hline Kedundung & 54 & 719 & 0 & 3.470 & 160 & 3 & 2 & 4 & 3 & 2 \\
\hline Gunung Gedangan & 71 & 228 & 0 & 1.531 & 165 & 1 & 3 & 3 & 2 & 1 \\
\hline \multicolumn{11}{|l|}{ Kranggan } \\
\hline Meri & 91 & 120 & 0 & 2.119 & 80 & 2 & 3 & 2 & 2 & 3 \\
\hline Miji & 61 & 189 & 0 & 2.193 & 117 & 2 & 2 & 2 & 3 & 2 \\
\hline Kranggan & 34 & 161 & 0 & 3.094 & 400 & 2 & 3 & 3 & 3 & 2 \\
\hline Sentanan & 34 & 37 & 0 & 469 & 133 & 4 & 3 & 2 & 2 & 3 \\
\hline Purwotengah & 80 & 0 & 0 & 516 & 0 & 1 & 3 & 1 & 2 & 1 \\
\hline Jagalan & 39 & 1 & 0 & 749 & 127 & 3 & 3 & 1 & 2 & 2 \\
\hline
\end{tabular}

Table 4: Exposure data on waste in Mojokerto city

\begin{tabular}{|c|c|c|c|c|c|c|c|}
\hline \multirow[b]{2}{*}{ Regency/Villages } & \multirow[b]{2}{*}{ IRS waste } & \multirow{2}{*}{$\begin{array}{l}\text { Secondary data } \\
\text { Total collected and transported waste }(\%)\end{array}$} & \multicolumn{5}{|c|}{ OPD perception } \\
\hline & & & Bappeda & $\mathrm{KLH}$ & $\mathrm{PU}$ & Dinkes & DKP \\
\hline \multicolumn{8}{|l|}{ Prajurit Kulon } \\
\hline Mentikan & 68 & 89 & 3 & 3 & 3 & 2 & 3 \\
\hline Pulorejo & 28 & 50 & 3 & 4 & 1 & 3 & 2 \\
\hline Kauman & 28 & 75 & 1 & 3 & 3 & 2 & 2 \\
\hline Blooto & 18 & 86 & 3 & 2 & 2 & 2 & 2 \\
\hline Surodinawan & 78 & 87 & 3 & 2 & 2 & 2 & 3 \\
\hline Prajurit Kulon & 26 & 78 & 2 & 2 & 2 & 2 & 2 \\
\hline \multicolumn{8}{|l|}{ Magersari } \\
\hline Magersari & 24 & 81 & 1 & 2 & 3 & 2 & 4 \\
\hline Gedongan & 51 & 83 & 1 & 3 & 3 & 2 & 2 \\
\hline Balongsari & 23 & 86 & 3 & 3 & 3 & 3 & 4 \\
\hline Wates & 14 & 86 & 1 & 2 & 3 & 2 & 4 \\
\hline Kedundung & 19 & 86 & 4 & 2 & 3 & 2 & 3 \\
\hline Gunung Gedangan & 27 & 100 & 2 & 3 & 2 & 3 & 4 \\
\hline \multicolumn{8}{|l|}{ Kranggan } \\
\hline Meri & 42 & 90 & 2 & 2 & 3 & 2 & 3 \\
\hline Miji & 29 & 86 & 1 & 2 & 3 & 2 & 2 \\
\hline Kranggan & 24 & 82 & 2 & 2 & 3 & 3 & 2 \\
\hline Sentanan & 25 & 88 & 3 & 3 & 3 & 2 & 2 \\
\hline Purwotengah & 24 & 90 & 1 & 2 & 3 & 1 & 2 \\
\hline Jagalan & 48 & 75 & 4 & 3 & 3 & 2 & 2 \\
\hline
\end{tabular}

Results of research data analy sis 2018

sanitation service improvement. Higher risk of sanitation health in avillage made the area prioritized for improvement in sanitation service. After that, the impact and exposure scores were weighed. The prioritization of the settlement sanitation services was made based on sanitation risk level of each village as follows.

Domestic wastewater: Based o the results of the risk analysis, some areas were prioritized to receive improvement in domestic wastewater services including (Table 5-7).
Table 5: Impact weighing of domestic wastewater

\begin{tabular}{lc}
\hline Impact data & Weigh (\%) \\
\hline IRS & 40 \\
Secondary data & 40 \\
OPD perception & 20 \\
\hline
\end{tabular}

Table 6: Exposure weighing of domestic wastewater

\begin{tabular}{lc}
\hline Exposure data & Weigh (\%) \\
\hline Population & 25 \\
Population density & 25 \\
Poverty rate & 25 \\
Area classification & 25 \\
\hline
\end{tabular}

Results of research data analy sis 2018 
Table 7: The determination of areas with domestic wastewater risk

\begin{tabular}{|c|c|c|c|c|c|c|c|}
\hline \multirow[b]{2}{*}{ Regency/Villages } & \multirow{2}{*}{$\begin{array}{l}\text { Exposure of } \\
\text { domestic } \\
\text { wastewater }\end{array}$} & \multicolumn{5}{|c|}{ Impact of domestic wastewater } & \multirow{2}{*}{$\begin{array}{c}\text { Areas with risk } \\
\text { of domestic } \\
\text { wastewater }\end{array}$} \\
\hline & & Population & Population density & Poverty rate & Urban/Rural functions & Impact score & \\
\hline \multicolumn{8}{|l|}{ Prajurit Kulon } \\
\hline Mentikan & 3.0 & 2.0 & 4 & 4.0 & 2 & 4.00 & 3.0 \\
\hline Pulorejo & 2.0 & 2.0 & 2 & 4.0 & 2 & 3.00 & 2.0 \\
\hline Kauman & 4.0 & 1.0 & 2 & 4.0 & 2 & 3.00 & 3.0 \\
\hline Blooto & 3.0 & 1.0 & 1 & 4.0 & 2 & 2.00 & 2.0 \\
\hline Surodinawan & 1.0 & 2.0 & 1 & 3.0 & 2 & 2.00 & 1.0 \\
\hline Prajurit Kulon & 1.0 & 2.0 & 1 & 4.0 & 2 & 3.00 & 1.0 \\
\hline \multicolumn{8}{|l|}{ Magersari } \\
\hline Magersari & 3.0 & 1.0 & 2 & 2.0 & 2 & 2.00 & 2.0 \\
\hline Gedongan & 3.0 & 1.0 & 2 & 2.0 & 2 & 2.00 & 2.0 \\
\hline Balongsari & 3.0 & 2.0 & 3 & 3.0 & 2 & 3.00 & 2.0 \\
\hline Wates & 1.0 & 4.0 & 1 & 1.0 & 2 & 2.00 & 1.0 \\
\hline Kedundung & 4.0 & 4.0 & 1 & 4.0 & 2 & 4.00 & 4.0 \\
\hline Gunung Gedangan & 3.0 & 2.0 & 1 & 4.0 & 2 & 3.00 & 2.0 \\
\hline \multicolumn{8}{|l|}{ Kranggan } \\
\hline Meri & 3.0 & 2.0 & 1 & 2.0 & 2 & 2.00 & 2.0 \\
\hline Miji & 3.0 & 2.0 & 2 & 4.0 & 2 & 3.00 & 2.0 \\
\hline Kranggan & 2.0 & 3.0 & 1 & 4.0 & 2 & 3.00 & 2.0 \\
\hline Sentanan & 2.0 & 1.0 & 2 & 2.0 & 2 & 2.00 & 1.0 \\
\hline Purwotengah & 2.0 & 1.0 & 1 & 1.0 & 2 & 1.00 & 1.0 \\
\hline Jagalan & 2.0 & 1.0 & 2 & 2.0 & 2 & 2.00 & 1.0 \\
\hline
\end{tabular}

Results of research data analy sis 2018

Kedundung village, extremely high-risk area (Highly prioritized):

- Massive population of 4.349 families

- Population density of 150 people/ha

- High number of poor families of 1.207 families

- Very high number of families who defecate in inappropriate places reaching up to 719 families

- Index of domestic wastewater management risk of 54 (medium)

- The domestic wastewater service for SPALD-S of 3.470 families and for SPALD-T of 160 families (Communal toilets of 120 families; Communal IPAL of 40 families)

- The majority of families do not perform regular septic tank drainage

- Kedundung village is adjacent to other villages that have medium to low risk, making it possible for Kendundung village to have strong chance to improve its domestic wastewater management

\section{Mentikan village and Kauman village, high-risk areas (prioritized village):}

- Population of mentikan village reached 2.005 families

- Population of kauman village reached 849 families

- The population density in Mentikan village was very high, reaching 500 people/ha

- The population density of Kauman village was 207 people/ha

- The number of poor families in Mentikan village was 534
- The number of poor families in Kauman village was 231

- The number of families in Mentikan village who defecate in inappropriate places reaching up to 190 families

- The number of families in Kauman village who defecate in inappropriate places reaching up to 203 families

- $\quad$ Risk index of domestic wastewater treatment was 39 (low) in Mentikan village

- The risk index of domestic wastewater management in Kauman village was 71 (high)

- The SPLAD-S access of domestic wastewater management service reached 1.815 families

- The access of domestic wastewater management service for SPALD-S in Kauman village has reached 526 families while SPALD-T has reached 120 families (Communal toilets for 100 families; Communal IPAL for 20 families)

- The majority of the community do not do regular septic tank drainage

- Mentikan and Kauman villages share spatial interaction with villages with medium-low risks. Hence, the improvement of wastewater management is expected to be effective

Household waste: The weighing of impact and exposure data: The analysis showed the areas prioritized to have improvement in waste management in Mojokerto city including (Fig. 1 and 2): 


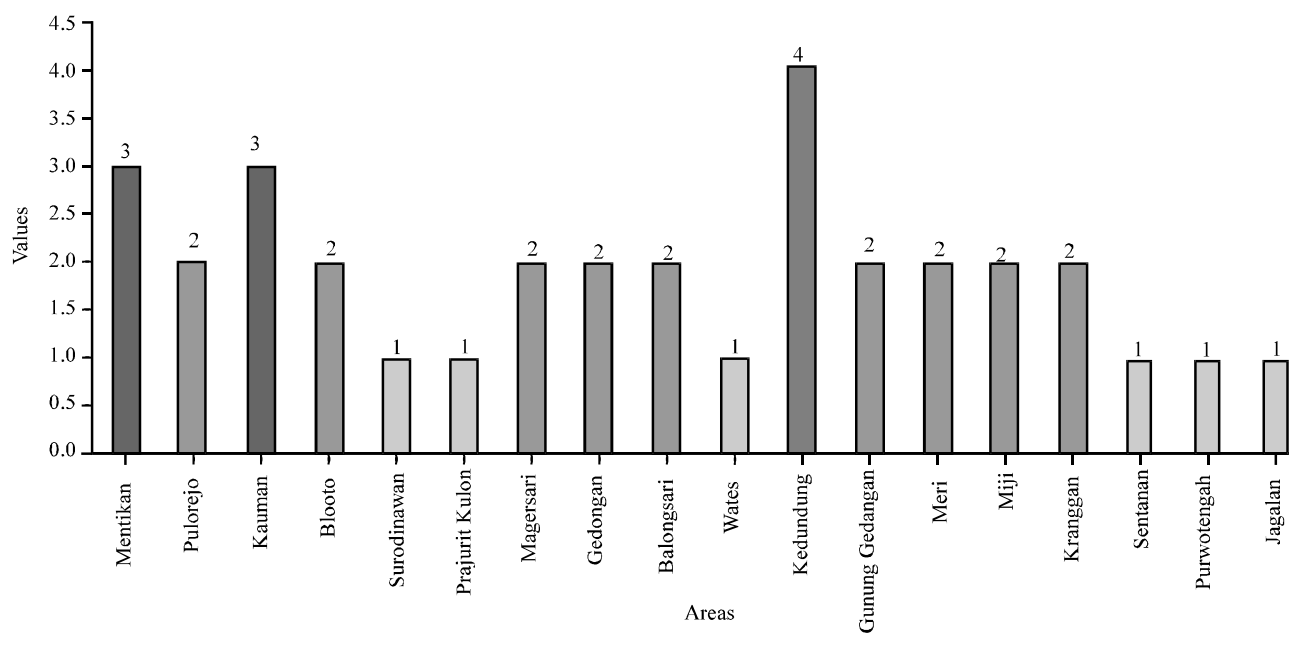

Fig. 1: The graph of areas prone to domestic wastewater in Mojokerto city

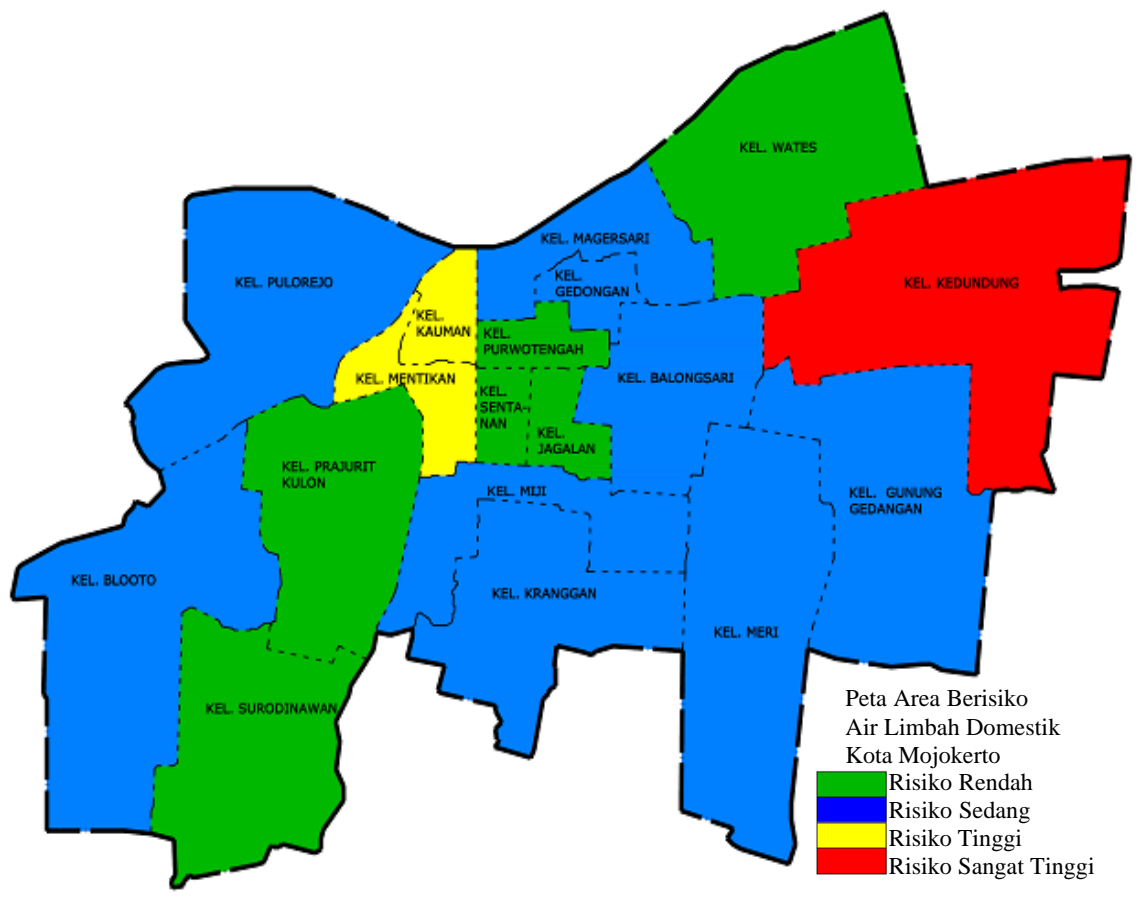

Fig. 2: The map of areas prone to domestic wastewater in Mojokerto city

- Mentikan village, high-risk area (highly-prioritized village)

- Large population of 2.055 families

- High population density of 500 people/ha

- Number of poor family reached 534 families

- Index of domestic wastewater risk of 68 (very high)

- Volume of landfill and transported waste of $89 \%$

- Only 1 landfill available

- $96.6 \%$ waste are not sorted (Table $8-10)$
Table 8: Waste impact weighing

\begin{tabular}{lc}
\hline Impact data & Weigh (\%) \\
\hline IRS & 40 \\
Secondary data & 40 \\
OPD perception & 20 \\
\hline & \\
Table 9: Waste exposure weighing & Weighing (\%) \\
\hline Exposure data & 25 \\
Population & 25 \\
Population density & 25 \\
Poverty rate & 25 \\
Area classification &
\end{tabular}


Table 10: Determination of areas prone to waste risks

\begin{tabular}{|c|c|c|c|c|c|c|c|}
\hline \multirow[b]{2}{*}{ Regency/Villages } & \multirow[b]{2}{*}{ Waste exposure } & \multicolumn{5}{|c|}{ Waste impact } & \multirow[b]{2}{*}{ High-risk area } \\
\hline & & Population & Population dnsity & Poverty rate & Urban function & Impact score & \\
\hline \multicolumn{8}{|l|}{ Prajurit Kulon } \\
\hline Mentikan & 4.0 & 2.0 & 4 & 4.0 & 2 & 4.00 & 4.0 \\
\hline Pulorejo & 4.0 & 2.0 & 2 & 4.0 & 2 & 3.00 & 3.0 \\
\hline Kauman & 3.0 & 1.0 & 2 & 4.0 & 2 & 3.00 & 3.0 \\
\hline Blooto & 2.0 & 1.0 & 1 & 4.0 & 2 & 2.00 & 1.0 \\
\hline Surodinawan & 4.0 & 2.0 & 1 & 3.0 & 2 & 2.00 & 2.0 \\
\hline Prajurit Kulon & 2.0 & 2.0 & 1 & 4.0 & 2 & 3.00 & 2.0 \\
\hline \multicolumn{8}{|l|}{ Magersari } \\
\hline Magersari & 2.0 & 1.0 & 2 & 2.0 & 2 & 2.00 & 1.0 \\
\hline Gedongan & 4.0 & 1.0 & 2 & 2.0 & 2 & 2.00 & 2.0 \\
\hline Balongsari & 2.0 & 2.0 & 3 & 3.0 & 2 & 3.00 & 2.0 \\
\hline Wates & 2.0 & 4.0 & 1 & 1.0 & 2 & 2.00 & 1.0 \\
\hline Kedundung & 2.0 & 4.0 & 1 & 4.0 & 2 & 4.00 & 2.0 \\
\hline Gunung gedangan & 1.0 & 2.0 & 1 & 4.0 & 2 & 3.00 & 1.0 \\
\hline \multicolumn{8}{|l|}{ Kranggan } \\
\hline Meri & 2.0 & 2.0 & 1 & 2.0 & 2 & 2.00 & 1.0 \\
\hline Miji & 2.0 & 2.0 & 2 & 4.0 & 2 & 3.00 & 2.0 \\
\hline Kranggan & 2.0 & 3.0 & 1 & 4.0 & 2 & 3.00 & 2.0 \\
\hline Sentanan & 2.0 & 1.0 & 2 & 2.0 & 2 & 2.00 & 1.0 \\
\hline Purwotengah & 1.0 & 1.0 & 1 & 1.0 & 2 & 1.00 & 1.0 \\
\hline Jagalan & 4.0 & 1.0 & 2 & 2.0 & 2 & 2.00 & 2.0 \\
\hline
\end{tabular}

Results of research data analy sis 2018

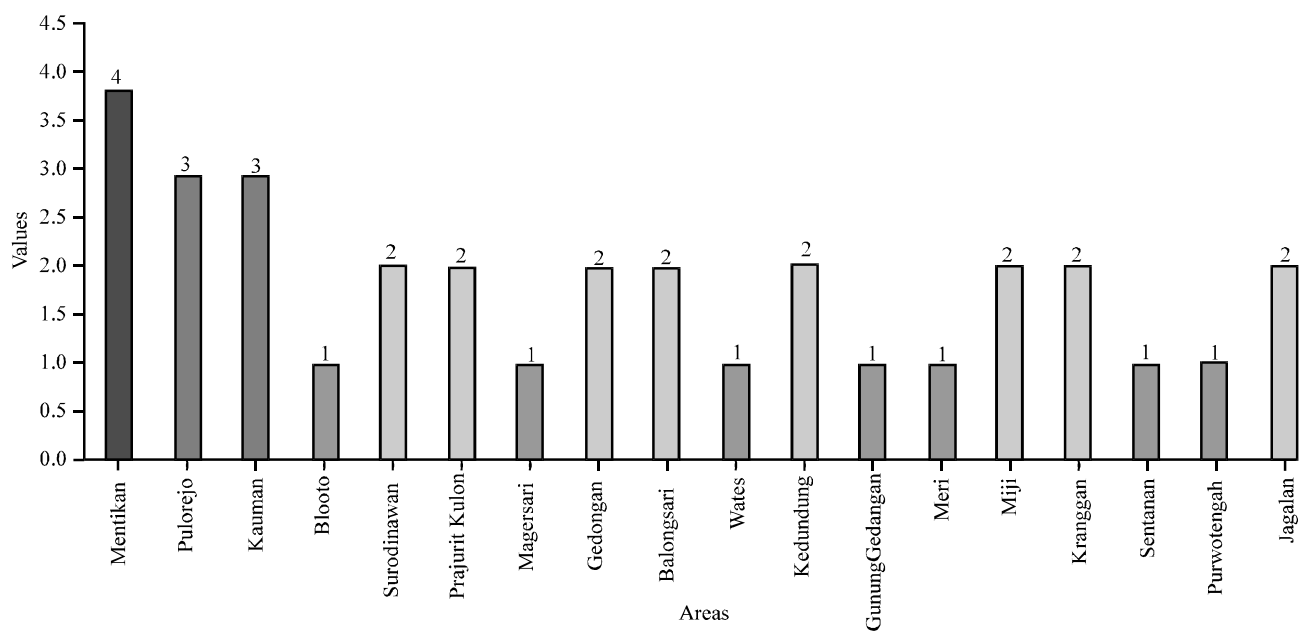

Fig. 3: The graph of areas prone to waste risks in Mojokerto city

Mentikan village shares spatial interaction with Pulorejo village and Kauman village that are high-risk areas, hence, the community in those areas tend to show similar behavior in waste management (Fig. 3 and 4).

\section{Pulorejo village and Kauman village, high-risk areas} (prioritized villages):

- Population of Pulorejo village reached 2.009 families

- Population of Kauman village reached 849 families

- The population density of Pulorejo village was 202 people/ha

- The population density of Kauman village was 207/ha

- The number of poor families in Pulorejo village reached 524
- The number of poor families in Kauman village reached 321

- The risk index of waste management in Pulorejo village was 28 (low)

- The risk index of waste management in Kauman village was 28 (low)

- The volume of landfill and transported waste in Pulorejo village reached $50 \%$

- The volume of landfill and transported waste in Kauman village reached $75 \%$

- No landfill in Pulorejo ville and it only owned 1 unit of 3R landfill

- No landfill in Kauman village

- Unsorted waste in Pulorejo village was 90.3\%

- Unsorted waste in Kauman village was $55.3 \%$ 


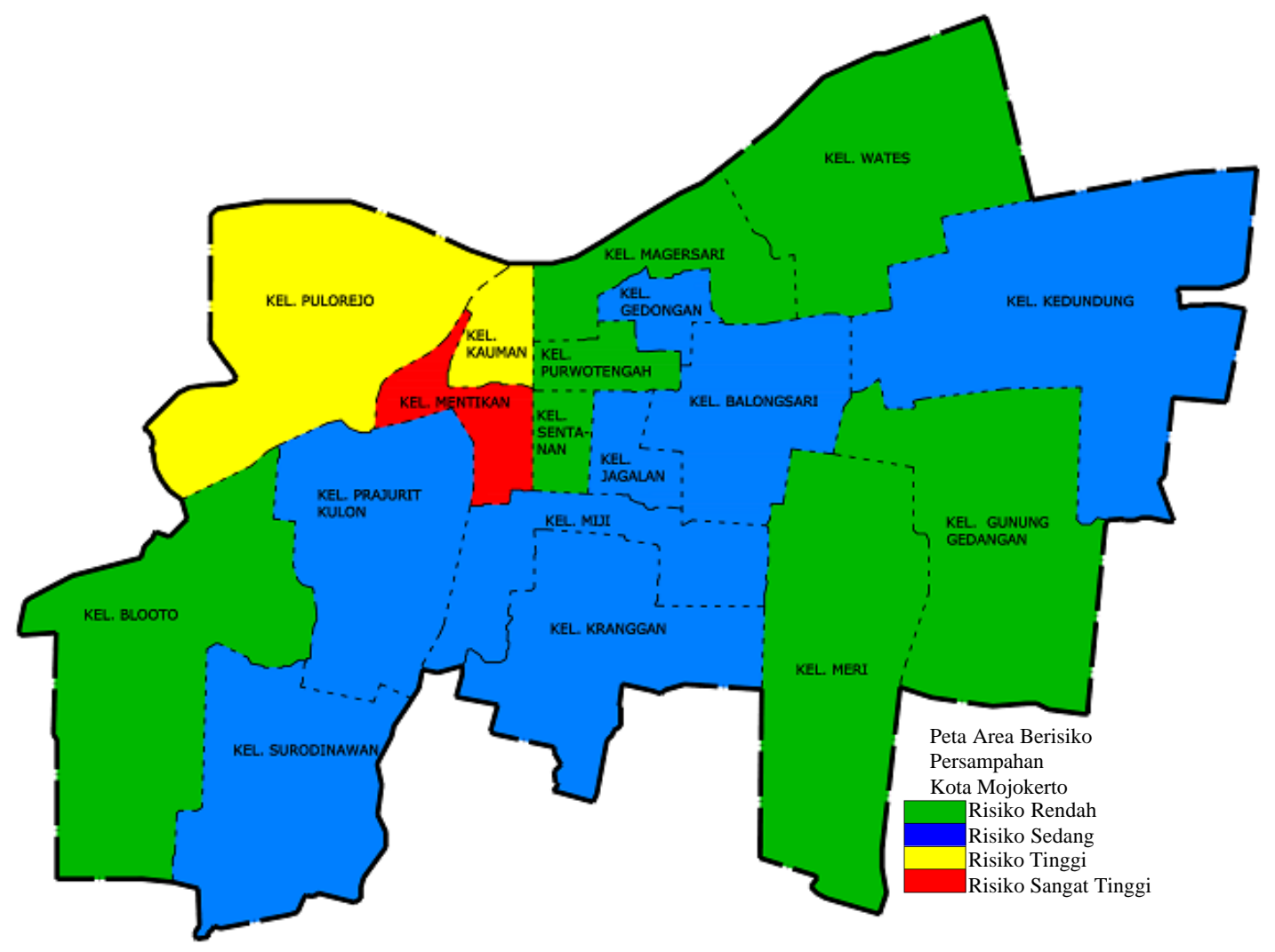

Fig. 4: The map of areas prone to waste risks in Mojokerto city

Pulorejo and Kauman villages share spatial interaction with Mentikan village which was a high-risk area. Hence, the community in those villages have similar behavior regarding waste management. Some part of those villages are adjacent to medium and low risk areas, making the improvement in waste management feasible.

\section{CONCLUSION}

Regarding to the results of analysis and research objectives, conclusions are drawn as follows: in technocratic planning method, prioritization of settlement sanitation service improvement goes proportionally with the results of sanitation risk level in each village regarding the management of domestic wastewater and household waste obtained as follows:

- Non-priority: (Green)

- Low-priority: (Blue)

- Priority: (Yellow)

- $\quad$ Strong priority: (Red)

In the context of spatial approach, spatial interaction among adjacent areas might influence other areas, including influences in the improvement of sanitation services, especially in prioritized villages. The use of spatial comparison also describes the comparison between several areas to determine the areas which are highly prioritized to receive improvement in sanitation services including domestic wastewater management and household waste management.

High-priority areas and prioritized areas should receive betterment in the forms of short-term programs (1-3 years) while villages that are less prioritized or non-prioritized can receive the medium-term ( 5 years) or long-term (10 years) programs.

\section{REFERENCES}

Adams, W.M., 2008. Green Development: Environmental and Sustainability in a Developing World. 3rd Edn., Routledge, Abingdon, UK., ISBN: 9781134158386, Pages: 480 .

Anonymous, 2008. [Law number 18 year 2008 about waste management]. PT. Justika Siar Publika, South Jakarta, Indonesia. (In Indonesian) https:// www.huk umonline. com/pusat data/detail/28066/node/1011/u ndangun dang-nomor-18-tahun-2008 
Anonymous, 2009. [Law Number 32 of 2009 concerning environmental protection and management]. Lembaga Studi \& Advokasi Masyarakat, South Jakarta, Indonesia. (In Indonesian) http://refe rensi.e lsam.or.id/2015/04/uu-nomor-32-tahun-2009-tentangperlindungan-dan-pengelolaan-lingkungan-hidup-2/

Anonymous, 2014a. [Law No. 23 of 2014 concerning regional government]. Yayasan Penelitian Inovasi Bumi (INOBU), Denpasar, Indonesia. (In Indonesian) http://inobu.org/how-can-redd-protect-the-rights-ofwest-papuans-and-the-environment- $1 /$ ?lang=id

Anonymous, 2014b. [Presidential Regulation (PERPRES) concerning the acceleration of the supply of water and sanitation]. Pemerintah Pusat, Indonesia. (In Detect) https:/ / peratur an.bpk. go.id/H ome/Deta ils/4170 4/perpre s-no-185-tahun-2014

Anonymous, 2017. [Presidential Regulation (PERPRES) concerning national policies and strategies for household waste management and household waste]. Pemerintah Pusat, Indonesia. (In Indonesian)

Anonymous, 2004. [Law Number 25 of 2004 concerning the national development planning system]. Kementerian Perencanaan Pembangunan Nasional, Jakarta, Indonesia. (In Indonesian) https:// www.bapp enas.go. id/id/dat a-dan- informa siutama/produk-hukum-peraturan-perundangan/ undang-undang/uu-no25-tahun-2004-tentang-sistemperencanaan-pembangunan-nasional-sp
Asiyanto, 2009. [Risk Management for Contractors]. Pradnya Paramita Publisher, Jakarta, Indonesia, (In Indonesian).

Craven, J., R. Gine Garriga, A. Jimenez Fernandez de Palencia and A. Perez Foguet, 2013. Introducing hygiene elements into sanitation monitoring. Proceedings of the 36th WEDC International Conference on Delivering Water, Sanitation and Hygiene Services in an Uncertain Environment, July 1-5, 2013, Nakuru, Kenya, ISBN: 9781843801535 , pp: 1-6.

Darmawi, H.M.R., 2010. [Risk Management]. Bumi Aksara, Jakarta, Indonesia, (In Indonesian).

Mardikanto, T., 1988. [Community Participation in Development]. Universitas Sebelas Maret, Surakarta, Indonesia, (In Indonesian).

Mojokerto, B.P.S.K., 2017. [City of Mojokerto in 2017 Figures]. BPS, Kota Mojokerto, Java, Indonesia, (In Indonesian).

Notoatmodjo, S., 2012. [Health Promotion and Health Behavior]. Rineka Cipta, Jakarta, Indonesia, (In Indonesian).

Rizki, B. and S. Saleh, 2007. [Linkages to sanitation access and poverty levels: A case study in central java province (In Indonesian)]. Econ. J. Emerg. Markets, 12: $223-233$.

Umar, H., 2008. [Research Methods for Thesis and Business Thesis]. Raja Grafindo Persada PT, Depok, Indonesia, ISBN:9789794217054, Pages: 385 (In Indonesian). 